\title{
Adsorption of methylene blue from aqueous solution using untreated and treated (Metroxylon spp.) waste adsorbent: equilibrium and kinetics studies
}

\author{
Jeminat O. Amode ${ }^{1} \cdot$ Jose H. Santos $^{1} \cdot$ Zahangir Md. Alam $^{2} \cdot$ Aminul H. Mirza $^{1}$ • \\ Chan C. Mei ${ }^{1}$
}

Received: 5 October 2015/ Accepted: 17 May 2016/Published online: 10 June 2016

(c) The Author(s) 2016. This article is published with open access at Springerlink.com

\begin{abstract}
Background (Metroxylon spp.) waste is an inexpensive and abundantly available material with the characteristics of a good adsorbent for treating dye from wastewater. We studied the effectiveness of alkali and acid modification in enhancing the adsorption capacity of sago waste. The untreated and treated adsorbent was characterized by FTIR, elemental analysis and BET surface area. The capacity of each adsorbent to adsorb MB was evaluated at different $\mathrm{pH}$ values, adsorbent dosage and initial dye concentrations and contact time.

Results According to the results obtained, alkali treatment more than doubled the sorption capacity of sago waste by increasing the porosity, surface area and number of adsorption sites. The alkali-treated material also adsorbed significantly more than many known biosorbents. The effects of the initial concentration of methylene blue, solution $\mathrm{pH}$ and adsorbent dosage on methylene blue removal are reported. Equilibrium data were best represented by the Langmuir isotherm model with adsorption capacities of 83.5, 212.8 and $36.82 \mathrm{mg} / \mathrm{g}$ for untreated, potassium hydroxide-treated and phosphoric acid-treated sago wastes, respectively. The kinetics of adsorption were best described by a pseudo-second-order model $\left(R^{2}=0.999\right)$.

Conclusions The alkali treatment of sago waste demonstrates the use of a low-cost agricultural waste and a simple
\end{abstract}

Jose H. Santos

jose.santos@ubd.edu.bn

1 Faculty of Science, Universiti Brunei Darussalam, Jalan Tungku Link, Gadong 1410, Negara Brunei Darussalam

2 Bioenvironmental Engineering Research Unit (BERU), Faculty of Engineering, International Islamic University Malaysia (IIUM), Kuala Lumpur, Malaysia modification process to produce an effective adsorbent for removing cationic dye from wastewater.

Keywords (Metroxylon spp.) waste - Methylene blue . Low-cost adsorbent · Adsorption - Alkali modification . Water treatment

\section{Introduction}

Wastewater effluents from many industries, including paper, leather, textiles, rubber, plastics, printing, cosmetics, pharmaceuticals and food, contain several kinds of synthetic dyestuffs [1]. Dye-bearing wastewaters exhibit high chemical and biochemical oxygen demands [2]. The presence of even very low concentrations in discharge effluents to the environment is worrying for both toxicological and esthetic reasons $[3,4]$. To reduce the negative effects of dye-contaminated wastewater on humans and the environment, the wastewater must be treated carefully before discharge into main streams [5]. Various physical, chemical and biological methods, including adsorption, biosorption coagulation and flocculation, advanced oxidation, ozonation, membrane filtration and liquid-liquid extraction, have been widely used for the treatment of dye-bearing wastewater [2, 6-8]. Adsorption is a very effective separation technique and is considered to be superior to other techniques for water treatment in terms of initial cost, simplicity of design, ease of operation and resilience to toxic substances $[9,10]$. Although adsorption technologies are well established, a significant limitation is the cost of adsorbent materials. This has motivated the search for low-cost and renewable materials for use as sorbents and has led to a growing interest in the use of nonconventional and locally available materials such as natural materials and agricultural wastes. 
Recently, a large number of low-cost adsorbents have been utilized to develop cheaper and effective adsorbents to remove dyes from wastewater, including cucumber peels [11], meranti sawdust [12], bagasse [13], durian leaf powder [14], watermelon seed hulls [11], grape pulp [15], chitosan [16, 17], kenaf core fibers [18], etc. The reported results showed that most of these readily available bioadsorbents possess high efficiency in removing dyes from aqueous solutions [16, 19]. These lignocellulosic byproducts possess various advantages, such as being ecofriendly, renewable, less expensive and abundantly available, as compared to commercial adsorbents [18, 20]. Studies have also shown that chemical modification of agricultural by-products significantly enhances their ionbinding properties, thereby providing greater flexibility in their applications to a wide range of dyes [21-24]. However, while agricultural by-products are often presented as low-cost adsorbents, their availability is often region specific. With the majority of costs in using biosorbents being associated with the transportation of materials [25], their viability may be limited to the region of origin. Agricultural waste is a low-cost and abundantly available material in Brunei Darussalam among other areas in the AsiaPacific region. (Metroxylon spp.) waste also known as sago hampas is a by-product of starch extraction from Metroxylon sagu (sago palm). Sago palm is becoming an important socioeconomic crop in countries such as Papua New Guinea, Indonesia, Malaysia, Thailand and the Philippines [26]. This biomass has good chemical stability, high mechanical strength and a granular structure, making it a good adsorbent material for treating dye from wastewater. In the present study, agricultural sago waste was treated with alkaline and acid for the removal of methylene blue from aqueous solutions. The enhancement of unmodified Metroxylon spp. waste by alkali and acid treatment has been investigated here toward the development of a dyeremoving adsorbent that is high in adsorption capacity, cost-effective and requires only simple processing. Batch studies were performed to evaluate the effects of various parameters such as $\mathrm{pH}$, initial dye concentration and adsorbent dosage on the removal of a basic dye from an aqueous solution. The textural and physicochemical properties, adsorption isotherms and kinetic parameters have also been determined and discussed.

\section{Materials and methods}

\section{Reagents}

The following chemical reagents were of analytical grade (AR) and purchased from Merck and Sigma Aldrich companies: orthophosphoric acid, potassium hydroxide,

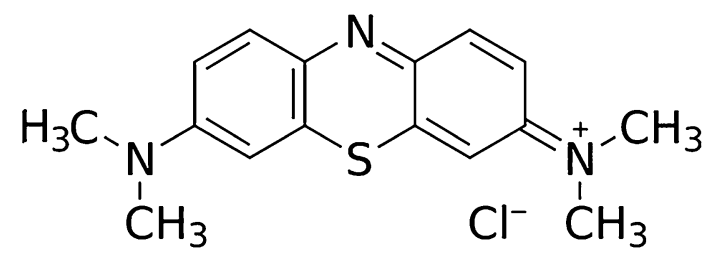

Fig. 1 The structure of methylene blue chloride salt

sodium chloride, sodium hydroxide, hydrochloric acid and methylene blue (MB). Methylene blue was chosen in this study because of its known strong adsorption onto solids and its recognized usefulness in characterizing adsorptive material [27]. Methylene blue has a molecular weight of $319.85 \mathrm{~g} \mathrm{~mol}^{-1}$, which corresponds to the heterocyclic aromatic chemical compound with the molecular formula $\mathrm{C}_{16} \mathrm{H}_{18} \mathrm{~N}_{3} \mathrm{SCl}$. Methylene blue has a net positive charge and the structure of this dye is shown in Fig. 1.

Stock solutions were prepared by dissolving an accurately weighed $1.000 \pm 0.0005 \mathrm{~g}$ of dye in $1 \mathrm{~L}$ of distilled water. Stock solutions were covered with aluminum foil and stored in a dark place to prevent UV degradation. The desired concentrations for batch adsorption tests were obtained by further dilution.

\section{Untreated adsorbent}

The sago hampas waste used in this study was obtained from a sago processing plant in Ukong, Tutong District, Brunei Darussalam. When used on a dry basis, sago hampas contains $58 \%$ starch, $23 \%$ cellulose, $9.2 \%$ hemicellulose and $4 \%$ lignin [28]. Sago hampas is the starchy lignocellulosic by-product from the pith of Metroxylon sagu (sago palm) following the starch extraction process [26]. Sago waste collected from the processing plant was washed repeatedly with distilled water to remove soluble impurities, such as excess starch, and solid wastes from the industrial process including adhering dirt and debris. The sago waste was then dried to drain excess water and then further dried in an $80{ }^{\circ} \mathrm{C}$ oven for $24 \mathrm{~h}$ prior to storage. The dried biomass was ground using a laboratory blender to a fine powder and screened with a standard sieve size to ensure that particle sizes were not greater than $350 \mu \mathrm{m}$. The powdered biomass was stored in an airtight plastic container and used for batch adsorption tests and characterization. Sago waste samples used without chemical treatment are denoted here as SW.

\section{Modification of sago waste adsorbent}

Alkali- and acid-treated sago waste adsorbent powders were prepared separately by mixing $10 \mathrm{~g}$ of the raw sample obtained after sieving with $100 \mathrm{ml}$ of diluted $\mathrm{H}_{3} \mathrm{PO}_{4}(85$ 
$\mathrm{wt} \%$ ) to a concentration of $(20.0 \%) \mathrm{w} / \mathrm{v}$ in a beaker. Similarly, $10 \mathrm{~g}$ of sieved sample was mixed with $100 \mathrm{ml}$ solution of dissolved $\mathrm{KOH}$ to a concentration of $(1.0 \mathrm{M})$ in a beaker. The reaction mixtures were stirred with a magnetic stirrer for a period of $24 \mathrm{~h}$ prior to filtration to achieve good penetration of chemical into the interior of the precursor.

After that, the chemically treated samples were subjected to thorough washing with hot water $\left(80^{\circ} \mathrm{C}\right)$, mild acid $(0.1 \mathrm{M} \mathrm{HCl})$ and base $(0.1 \mathrm{M} \mathrm{NaOH})$ till the effluent water shows the neutral $\mathrm{pH}$. The samples were dried at $70{ }^{\circ} \mathrm{C}$ overnight and used for batch adsorption tests and characterization. The treated sago wastes are denoted as SKOH and SHP for alkali- and acid-treated adsorbents, respectively.

\section{Characterization of adsorbent}

The method for determining the point of zero charge, $\mathrm{pH}_{\mathrm{PZC}}$, for adsorbents is described elsewhere [29]. Briefly, $50 \mathrm{~mL}$ of $0.01 \mathrm{M} \mathrm{KNO}_{3}$ solutions were placed in various Erlenmeyer flasks. The $\mathrm{pH}$ of the solutions was adjusted to values between 2 and 10 by the addition of $0.1 \mathrm{M} \mathrm{HCl}$ and $\mathrm{NaOH}$ solutions. For each solution, $0.2 \mathrm{~g}$ of adsorbent powder was added and the final $\mathrm{pH}$ recorded after $48 \mathrm{~h}$. The $\mathrm{pH}_{\mathrm{PZC}}$ is the point where $\mathrm{pH}_{\text {final }}$ and $\mathrm{pH}_{\text {initial }}$ values are equal.

The Boehm titration method was applied to determine the amounts of acidic and basic surface functional groups. The main principle of this method is that surface oxygen groups are either acidic or basic moieties that are neutralized by bases and acids, respectively [30]. Prior to analysis, the adsorbent samples were dried in an oven at $110{ }^{\circ} \mathrm{C}$ for $3 \mathrm{~h}$. For each adsorbent, $0.2 \mathrm{~g}$ amounts were placed in stoppered glass flasks and $30 \mathrm{~mL}$ of either $0.1 \mathrm{M} \mathrm{NaOH}$ or $0.1 \mathrm{M} \mathrm{HCl}$ was added. The bottles were sealed and shaken at $250 \mathrm{rpm}$ for $48 \mathrm{~h}$ at $298 \mathrm{~K}$ to reach equilibrium. Suspensions at equilibrium were filtered and $20 \mathrm{~mL}$ of each filtrate was pipetted into $100 \mathrm{~mL}$ Erlenmeyer flasks. Filtrates containing excesses of $\mathrm{NaOH}$ and $\mathrm{HCl}$ were titrated with $0.1 \mathrm{M} \mathrm{HCl}$ and $0.1 \mathrm{M} \mathrm{NaOH}$, respectively. The numbers of acidic and basic sites were calculated by determining the amounts of $\mathrm{NaOH}$ and $\mathrm{HCl}$ that reacted with the adsorbents [30]. The specific surface area was calculated from the amount of adsorbed methylene blue at maximum adsorption capacity according to:

Specific Surface Area $=\frac{M_{M B} A_{v} A_{M B}}{319.85} \times \frac{1}{M_{S}}$,

where $M_{M B}$ is the mass ( $\mathrm{g}$ ) of methylene blue adsorbed at the point of maximum adsorption; $M_{s}$ is the mass $(\mathrm{g})$ of the adsorbents; $A_{v}$ is Avogadro's number, $6.02 \times 10^{23}$; and $A_{M B}$ is the area covered by one methylene blue molecule (typically assumed to be $1.62 \times 10^{-18} \mathrm{~m}^{2}$ ) [31]).
The physical properties such as specific surface area and pore volume distribution were measured by the nitrogen gas adsorption technique using a surface area analyzer (Quantachrome Corporation, USA) with liquid nitrogen at $77 \mathrm{~K}$. The surface area was calculated using the Brunauer-EmmettTeller (BET) method. Prior to the experiment, the samples were out-gassed at $393 \mathrm{~K}$ for $5 \mathrm{~h}$. Field emission scanning electron microscopy (FESEM) images were obtained using a Superscan SS-550 field emission scanning electron microscope (Shimadzu Corporation; Kyoto, Japan) and used to investigate the surface morphologies of adsorbents. The effects of chemical treatment on the surface functionalization of adsorbents were evaluated by Fourier transform infrared spectroscopy (FTIR) with spectra recorded between 4000 and $400 \mathrm{~cm}^{-1}$ (resolution of $4 \mathrm{~cm}^{-1}$ and acquisition rate of 32 scan min $^{-1}$ ) using an IR Prestige-21/FTIR-8400S spectrometer (Shimadzu Corporation; Kyoto, Japan).

\section{Batch adsorption experiments}

The effects of experimental parameters, such as MB concentration (75, 150 and $300 \mathrm{ppm}), \mathrm{pH}(2-12)$ and adsorbent dosage $(1-10 \mathrm{~g} / \mathrm{L})$ on dye adsorption by treated and untreated sago wastes, were studied in batch adsorption experiments. The $\mathrm{pH}$ of the experimental solutions was adjusted by the addition of $\mathrm{HCl}$ and $\mathrm{NaOH}$. All adsorption experiments were conducted in $250 \mathrm{~mL}$ conical flasks with $50 \mathrm{~mL}$ of dye solution (with the desired concentration and $\mathrm{pH}$ ) for $\mathrm{pH}$ tests and $100 \mathrm{~mL}$ for adsorbent dosage tests added to SW, SKOH and SHP adsorbents. The solutions were mechanically agitated in a rotary shaker at $250 \mathrm{rpm}$ and at a constant temperature of $298 \mathrm{~K}$. For studies of $\mathrm{pH}$ and adsorbent dosage at initial dye concentrations of $300 \mathrm{mg} / \mathrm{L}$, respectively, equilibrium was achieved within $2 \mathrm{~h}$. The solutions were then filtered through Whatman No. 40 filter paper and the absorbance of filtrates was determined using a UV/visible spectrophotometer (PerkinElmer; USA) at a maximum wavelength of $665 \mathrm{~nm}$. The MB concentrations were calculated from a calibration curve. The amounts of adsorbed dye per gram of adsorbent at equilibrium, $q_{e}(\mathrm{mg} / \mathrm{g})$, and the percentage removal $\left(R_{E}\right)$ were calculated by the following equations:

$q_{e}=\frac{\left(C_{0}-C_{e}\right) V}{W}$

$\% R_{E}=\frac{\left(C_{0}-C_{e}\right) 100}{C_{0}}$

where $C_{O}$ and $C_{e}$ are the initial and equilibrium concentrations of $\mathrm{MB}$, respectively $(\mathrm{mg} / \mathrm{L}) . V$ is the volume of dye solution (L) and $W$ is the mass of the adsorbent used (g).

Adsorption isotherm experiments were carried out by agitating $\mathrm{MB}$ solutions of different concentrations 
(10-1000 mg/L) with $0.1 \mathrm{~g}$ of adsorbent at a constant temperature of $298 \mathrm{~K}$. To ensure full equilibration, a shaking time of $120 \mathrm{~min}$ was used for all concentrations of MB. To study the kinetics of biosorption, $0.1 \mathrm{~g}$ of different adsorbents was added to $50 \mathrm{~mL}$ of dye solutions at initial concentrations of 75, 150 and $300 \mathrm{mg} / \mathrm{L}$. Aqueous samples were taken at different time intervals for the measurement of $\mathrm{MB}$ concentration.

\section{Results and discussion}

\section{Characterization of adsorbents}

The effect of chemical treatment on the surface structure of adsorbents was investigated by Fourier transform infrared spectroscopy (FTIR) (Fig. 2). Beyond the fingerprint region, a characteristic, broad band in all adsorbents occurs in the range of $3780-3000 \mathrm{~cm}^{-1}$ corresponding to the stretching mode of free $\mathrm{O}-\mathrm{H}$ groups, hydrogen-bonded $\mathrm{O}-$ $\mathrm{H}$ and chemisorbed water. A peak at $2920 \mathrm{~cm}^{-1}$ for all samples can also be assigned to the $\mathrm{C}-\mathrm{H}$ stretching of lignocellulosic components. While the composition of surface functional groups may differ between adsorbents, a notable feature of all samples is the presence of surface oxygen groups able to undergo protonation and deprotonation, and thus carry a surface charge.

The surface charge of adsorbents was further examined by comparing the $\mathrm{pH}_{\mathrm{PZC}}$ and $\mathrm{pH}$ of the adsorbent samples.
Surface charges arise from the presence of functional groups, such as surface oxygen complexes, and their interactions with the aqueous solution. The charge of each functional group contributes to the overall charge of the surface. When the solution $\mathrm{pH}$ is higher than the $\mathrm{pH}_{\mathrm{PZC}}$, the surface of the adsorbent has an overall negative charge, favoring the adsorption of cationic species. Alternatively, a solution $\mathrm{pH}$ below the $\mathrm{pH}_{\mathrm{PZC}}$ results in an overall positive surface charge and preferential adsorption of anionic species. The $\mathrm{pH}$ and $\mathrm{pH}_{\mathrm{PZC}}$ values for chemically treated adsorbents are listed in Table 1. For the untreated adsorbent, the $\mathrm{pH}_{\mathrm{PZC}}$ falls within a broad range. The $\mathrm{pH}$ of $\mathrm{SW}$ in solution is very similar to the $\mathrm{pH}_{\mathrm{PZC}}$ and so the untreated adsorbent is not considered to have an overall surface charge when added to aqueous solutions. A pH value above the $\mathrm{pH}_{\mathrm{PZC}}$ indicated an overall positive charge for the SHP samples. For $\mathrm{SKOH}$, the $\mathrm{pH}$ was also above the $\mathrm{pH}_{\mathrm{PZC}}$ and a greater difference in these values indicated that the surface charge is more negatively charged compared with SW samples. The overall negative charge on SKOH adsorbents suggests a potential for adsorbing positively charged MB molecules.

The proportions of basic and acidic groups on the adsorbent surface obtained by Boehm titration are also shown in Table 1. All adsorbent samples indicated the presence of basic functional groups and thus the potential to act as MB adsorbents. The largest number of basic groups was found in $\mathrm{SKOH}$ and this is in good agreement with the overall surface charge indicated by comparison of
Fig. 2 FTIR spectra of SW (below), SKOH (middle) and SHP (top)

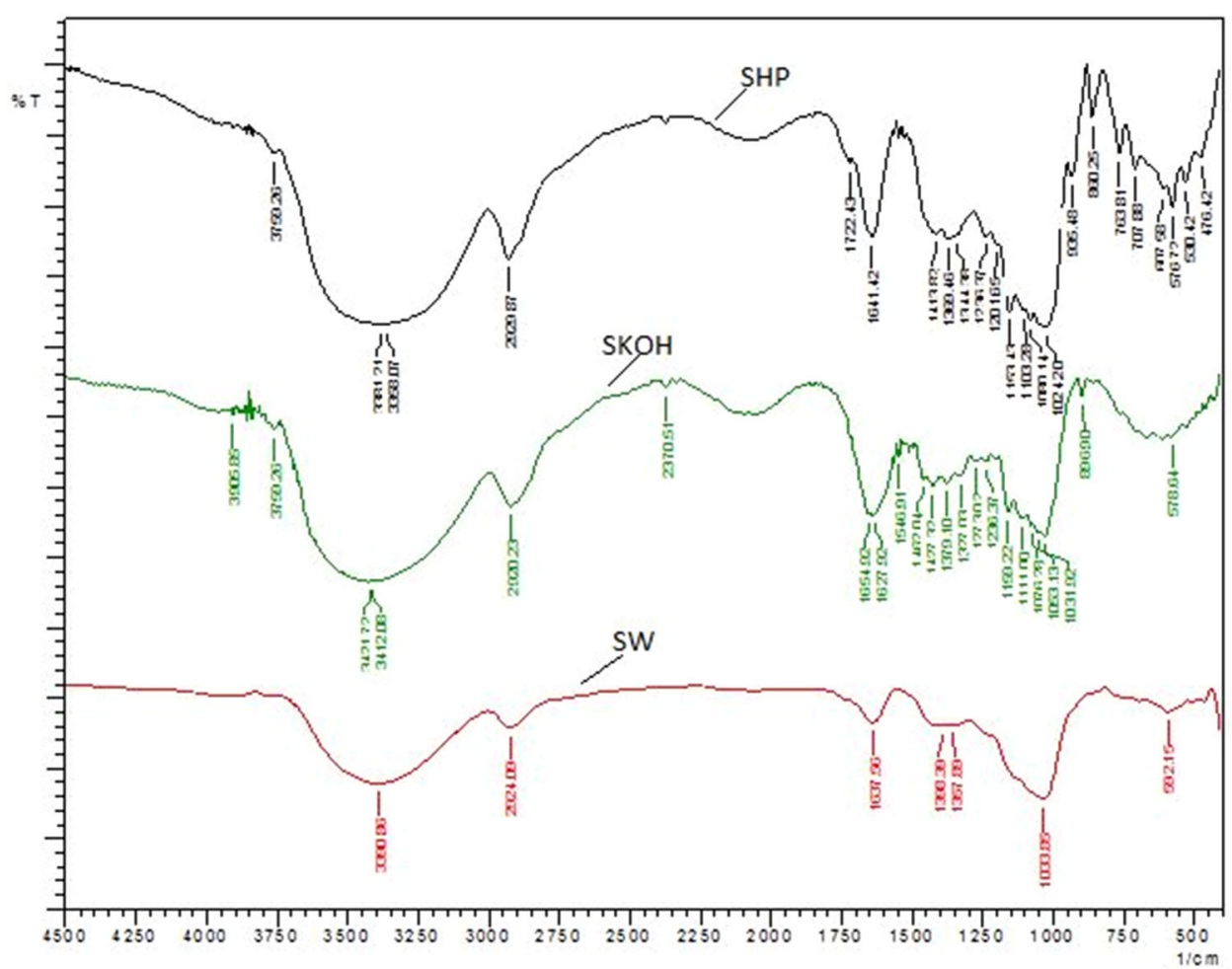


Table 1 Physiochemical properties of the untreated and chemically treated Metroxylon sagu waste adsorbents

\begin{tabular}{|c|c|c|c|c|c|c|c|c|c|}
\hline \multirow[t]{2}{*}{ Composition } & \multirow[t]{2}{*}{$\mathrm{pH}$} & \multirow[t]{2}{*}{$\mathrm{pH}_{\mathrm{PZC}}$} & \multirow{2}{*}{$\begin{array}{l}\text { Surface basic } \\
\text { group (meq) }\end{array}$} & \multirow{2}{*}{$\begin{array}{l}\text { Surface acidic } \\
\text { group (meq) }\end{array}$} & \multirow{2}{*}{$\begin{array}{l}\text { Specific surface } \\
\text { area }\left(\mathrm{S}_{\mathrm{MB}}\right) \mathrm{m}^{2} / \mathrm{g}\end{array}$} & \multicolumn{4}{|c|}{ Langmuir isotherm } \\
\hline & & & & & & $R^{2}$ & $q_{\max }(\mathrm{mg} / \mathrm{g})$ & $q_{\max }(\mathrm{mmol} / \mathrm{g})$ & $R_{L}$ \\
\hline SW & 5.61 & 6.75 & 0.79 & - & 246.4 & 0.9917 & 83.48 & 0.261 & 0.098 \\
\hline SKOH & 7.29 & 7.17 & 2.1 & 1.3 & 549.4 & 0.9979 & 212.8 & 0.665 & 0.550 \\
\hline SHP & 4.08 & 3.04 & 0.5 & 0.26 & 75.6 & 0.9488 & 36.82 & 0.115 & 0.101 \\
\hline
\end{tabular}

$\mathrm{pH}$ and $\mathrm{pH}_{\mathrm{PZC}}$ values. However, the number of basic groups is lower for SHP than $\mathrm{SW}$ despite $\mathrm{pH}$ and $\mathrm{pH}_{\mathrm{PZC}}$ values indicating that SHP is more likely to have an overall positive charge than SW. The specific surface area was increased from 246.4 to $549.4 \mathrm{~m}^{2} / \mathrm{g}$ for $\mathrm{SW}$ and $\mathrm{SKOH}$ and a significant decrease to $75.6 \mathrm{~m}^{2} / \mathrm{g}$ for SHP is in agreement with the number of negatively charged functional groups available for adsorbing MB molecules.

The creation of the nitrogen adsorption-desorption curve provides qualitative information on the adsorption mechanism and porous structure of the materials. The $\mathrm{N}_{2}$ adsorption-desorption isotherms and the pore size distribution by density functional theory (DFT) method of the untreated and treated sago waste was shown in Fig. 3. This adsorption behavior exhibits a combination of microporous-mesoporous structure. However, the adsorbents bear a resemblance to Type III isotherms which are generally obtained in case of nonporous adsorbents. The surface physical parameters obtained from the $\mathrm{N}_{2}$ adsorptiondesorption isotherms are summarized in Table 2. From the data, it is evident that the BET surface area, micropore surface area and total pore volume of SKOH were greatly improved after alkali treatment. The BET surface area of $\mathrm{SKOH}$ was obtained as $78.48 \mathrm{~m}^{2} / \mathrm{g}$, which may likely supply more surface active sites, leading to an enhancement of adsorption performance. It is suggested that the pore structure of the adsorbent $\mathrm{SKOH}$ consists of mesopores and micropores. The total pore volume at $P /$ Po $=0.989$ was obtained as $0.157 \mathrm{~cm}^{3} / \mathrm{g}$, which indicated that $\mathrm{SKOH}$ has a mesoporous structure and makes it easy for methylene blue to penetrate into the mesopores of SKOH. Among the experimental samples, the alkali treatment $(\mathrm{SKOH})$ had the highest surface area followed by untreated waste $\left(\mathrm{SW}=32.01 \mathrm{~m}^{2} / \mathrm{g}\right)$ and acid treatment $\left(\mathrm{SHP}=30.07 \mathrm{~m}^{2} / \mathrm{g}\right)$. However, the SHP sample and untreated samples showed only an insignificant pore volume. Earlier reports on rice straw fly ash (RSFA) found a higher surface $\left(67.4 \mathrm{~m}^{2} / \mathrm{g}\right)$ than our untreated samples [32]. This could be attributed to the quality of substrates where both the samples were of a fibrous nature.

It is evident that acid and alkali treatments affect the number of charged functional groups on the adsorbent surface. The correlation to the surface morphology was examined by field emission scanning electron microscopy (FESEM) of adsorbent samples (shown in Fig. 4). FESEM micrographs were obtained before and after treatment at an accelerating voltage of $10 \mathrm{kV}$ and $1000 \times$ magnification. At such magnification, distinct differences in the surface
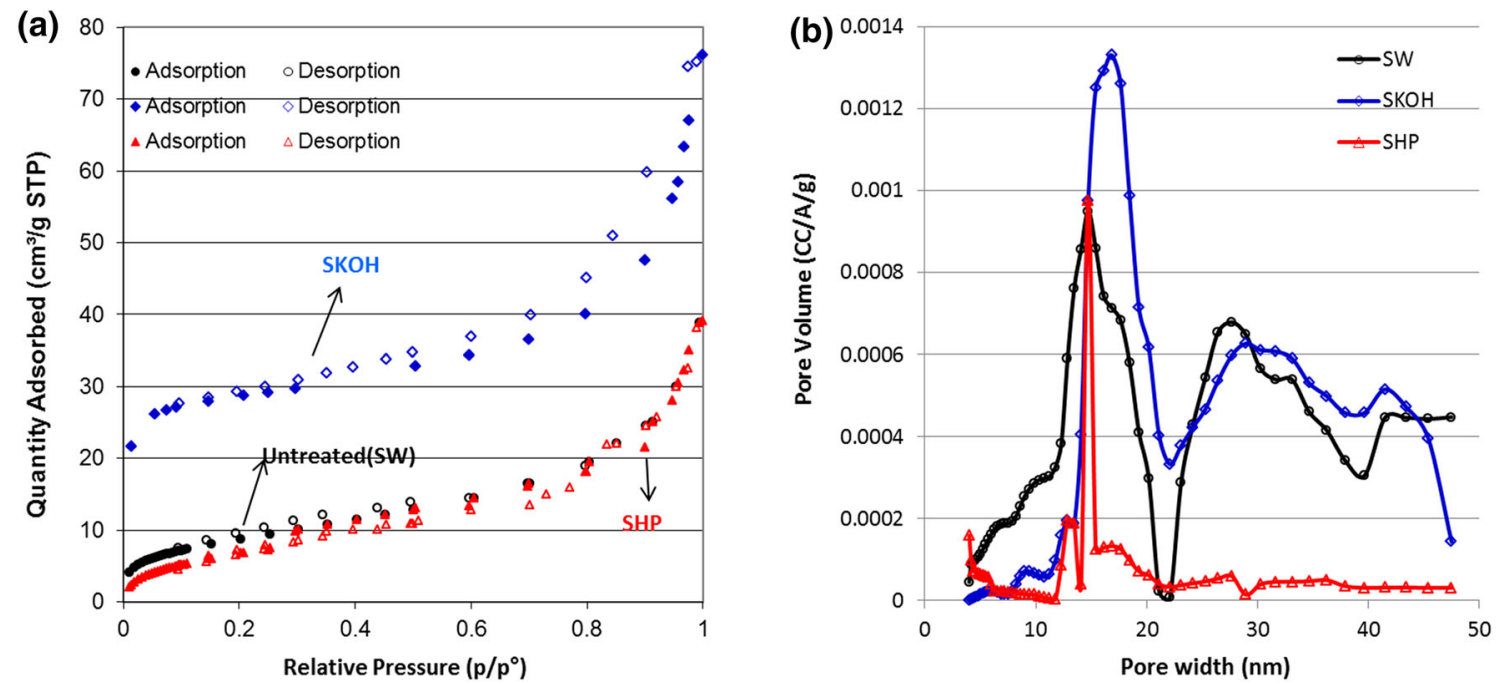

Fig. 3 a Nitrogen adsorption/desorption isotherms; b density functional theory (DFT) pore volume distribution of the untreated and treated sago waste 
Table 2 Surface area of the untreated and treated samples

\begin{tabular}{lllllc}
\hline Sample & $\begin{array}{l}\text { Total surface area (BET) } \\
\left(\mathrm{m}^{2} \mathrm{~g}^{-1}\right)\end{array}$ & $\begin{array}{l}\text { Micropore surface area } \\
\left(\mathrm{m}^{2} \mathrm{~g}^{-1}\right)\end{array}$ & $\begin{array}{l}\text { Total pore volume } \\
\left(\mathrm{cm}^{3} \mathrm{~g}^{-1}\right)\end{array}$ & $\begin{array}{l}\text { Micropore volume } \\
\left(\mathrm{cm} \mathrm{g}^{-1}\right)\end{array}$ & $\begin{array}{l}\text { Average pore } \\
\text { diameter }(\AA)\end{array}$ \\
\hline SW & 32.01 & 39.48 & 0.015 & 0.014 & 188.1 \\
SKOH & 78.48 & 56.64 & 0.157 & 0.012 & 74.84 \\
SHP & 30.07 & 28.78 & 0.014 & 0.014 & 202.3 \\
\hline
\end{tabular}
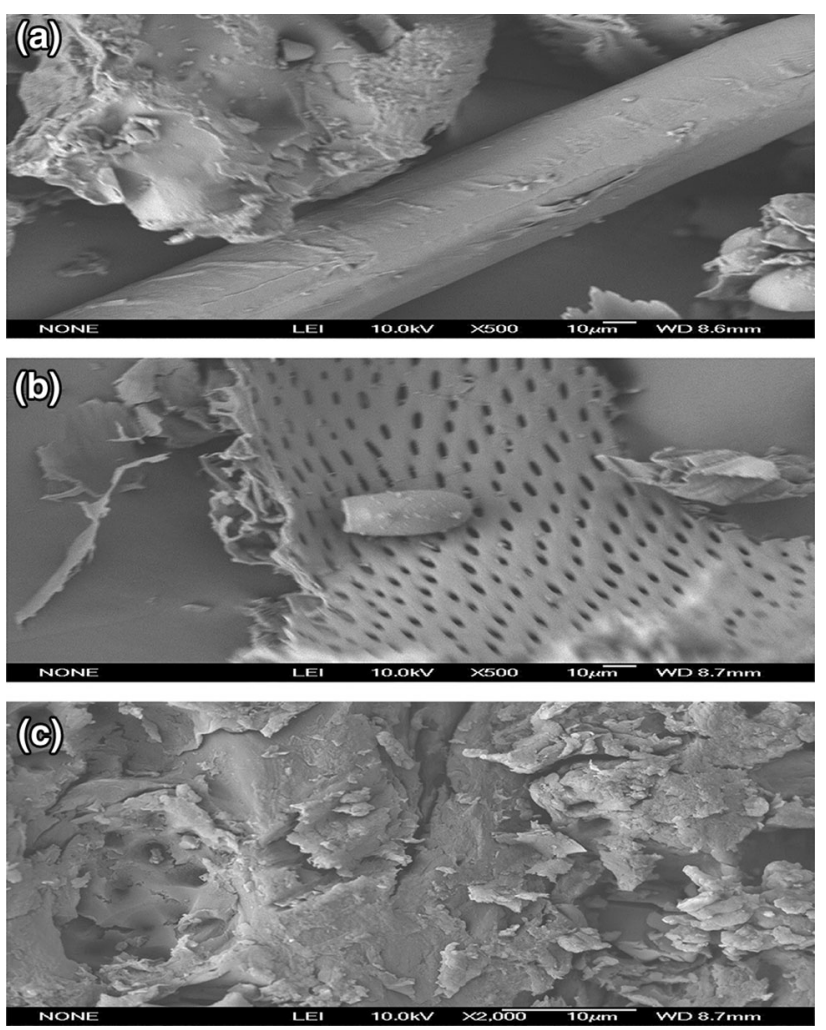

Fig. 4 FESEM images of a untreated (SW), b KOH-treated (SKOH) and $\mathbf{c} \mathrm{H}_{3} \mathrm{PO}_{4}$-treated (SHP) sago wastes

structure and porosity were clearly identifiable. After alkali treatment (Fig. 4b), the fibrous structure of the sago waste had clearly increased in surface roughness with the formation of pores throughout the structure. A previous study in which rice husk was exposed to $\mathrm{NaOH}$ demonstrated the dissolution of hemicellulose and lignin by alkali treatment and suggests that the increased porosity observed here is due to a similar dissolution of hemicellulose and lignin from the interfibrillar region of the sago hampas [33]. The increased porosity in SKOH not only increased the surface area of the adsorbent, but also the number of surface functional groups available as adsorption sites. This is reflected in the higher numbers of both basic and acidic functional groups listed in Table 1 for $\mathrm{SKOH}$.

Acidification of sago waste with phosphoric acid, unlike alkali treatment, showed no indication of visible pores. Like the raw sago waste, SHP exhibited a rough surface morphology with a larva-like structure. However, comparison of FESEM images (Fig. 4a, c) also showed swelling or enlargement of particles in SHP and a decrease in surface roughness. The images suggest a decrease in both porosity and surface area. A lower surface area would also decrease the number of functional groups exposed and accounts for the lower numbers of basic and acidic groups observed for SHP compared with SW and SKOH.

\section{Effect of initial dye concentration and contact time}

In all cases, an initially high rate of adsorption occurred because the MB concentration provided the driving force for the rapid attachment of MB onto the adsorbent surface. As adsorption proceeded, the ratio of MB molecules to available adsorption sites decreased, which resulted in a decrease in the adsorption rate until equilibrium was reached [34]. This behavior can be seen in Fig. 5a-c, for all adsorbents, and an increase in the initial concentration of MB also resulted in higher initial rates of adsorption. An increase in the initial concentration of $\mathrm{MB}$ corresponded to an increase in the ratio of $\mathrm{MB}$ molecules to available adsorption sites. This may have subsequently increased the initial driving force for the adsorption of $\mathrm{MB}$ by the adsorbent and led to a higher initial rate of adsorption. Figure 5a-c also shows that, in all cases, the time to equilibrium was completely reached within 30-60 min.

\section{Effect of $\mathbf{p H}$}

One of the important parameters in biosorption is the effect of $\mathrm{pH}$. The effect of $\mathrm{pH}$ on the adsorption of $\mathrm{MB}$ onto untreated SW, treated SKOH and SHP was investigated at a $\mathrm{pH}$ range of $2-12$ and is shown in Fig. 6. At ambient $\mathrm{pH}$, under the conditions employed, $79.04 \mathrm{mg} / \mathrm{g} \mathrm{MB}$ was adsorbed by SW (Fig. 6). As the $\mathrm{pH}$ increases from $\mathrm{pH} 4$ to 12 , there was a steady decrease in the amount of MB being adsorbed. The effect was the greatest at $\mathrm{pH} 12$ where a reduction of $4.53 \mathrm{mg} / \mathrm{g} \mathrm{MB}$ was observed. This effect was also reported for other low-cost biosorbents such as kenaf fiber char [35]. The high adsorption of SKOH between $\mathrm{pH}$ values of 6 and 10 can be attributed to electrostatic attraction between the negative charges of the adsorbent surface and the positive charge of the MB cation, since the amount of dye being removed was high $(>140 \mathrm{mg} / \mathrm{g})$ at 

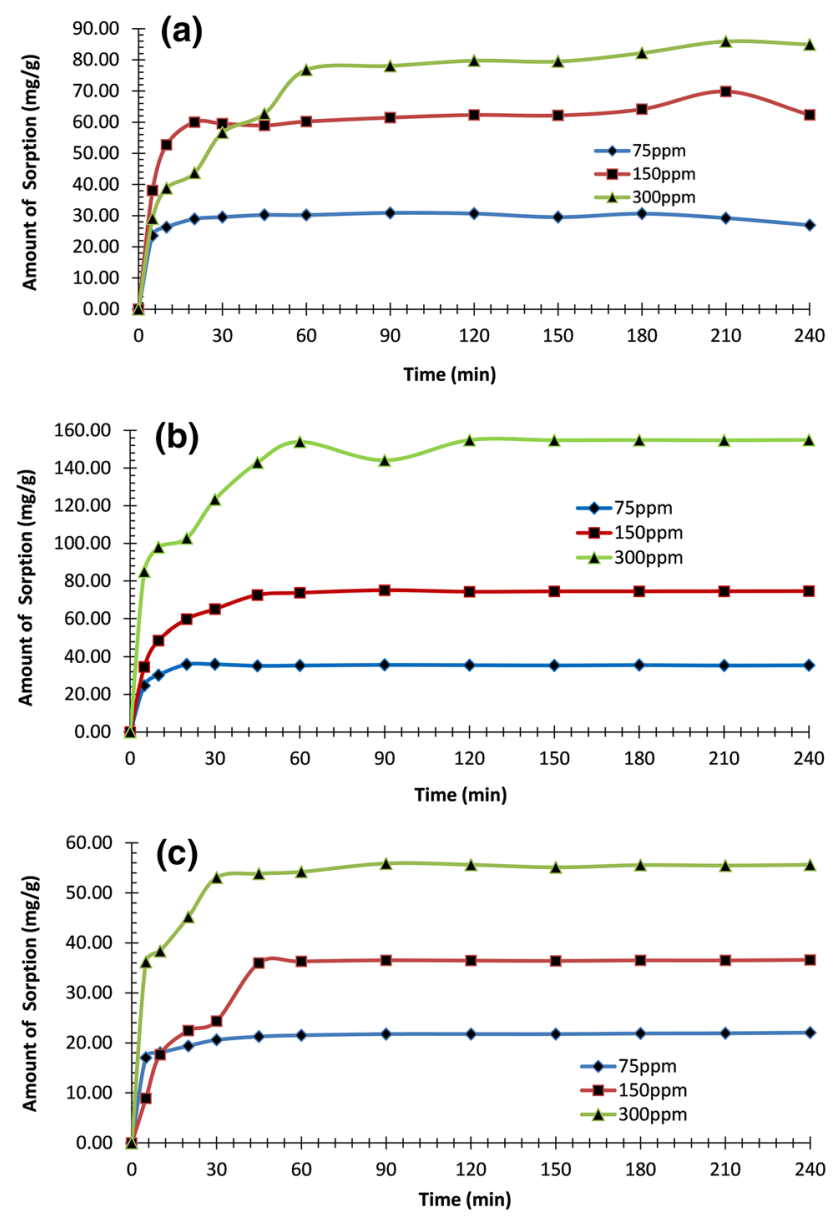

Fig. 5 Effect of initial concentration and contact time on the sorptive capacity of MB on a SW, b SKOH and c SHP $\left(C_{0}=75,150\right.$ and $300 \mathrm{mg} / \mathrm{L} ; \quad$ dosage $=0.1 \mathrm{~g} ; \quad$ working volume $=50 \mathrm{~mL}$; initial $\mathrm{pH}=$ ambient; agitation speed $=250 \mathrm{rpm}$ )

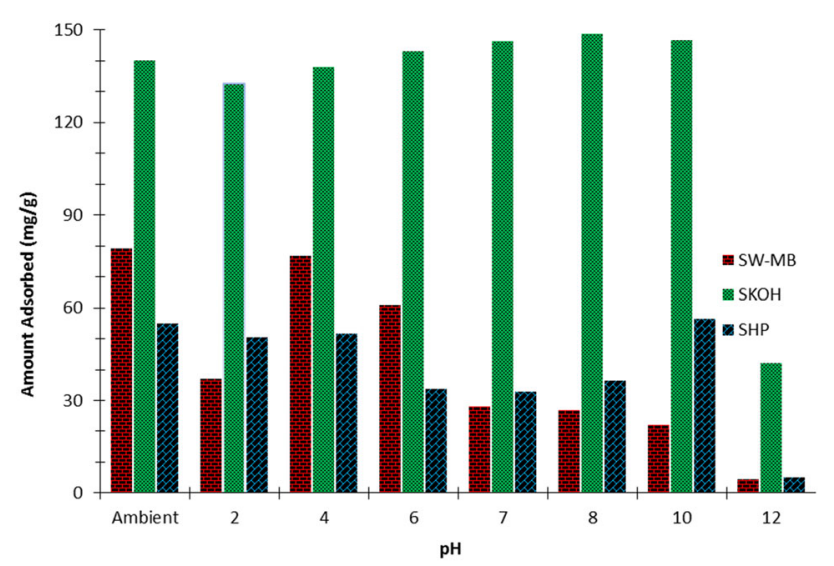

Fig. 6 Effect of solution $\mathrm{pH}$ on the adsorption of $\mathrm{MB}$ on $\mathrm{SW}$, SKOH and SHP $\left(C_{0}=300 \mathrm{mg} / \mathrm{L} ; \quad\right.$ dosage $=0.1 \mathrm{~g}$; working volume $=50 \mathrm{~mL}$; agitation speed $=250 \mathrm{rpm}$

ambient $\mathrm{pH}(\mathrm{MB}=4.6)$, as compared to that of other adsorbent $\mathrm{pH}$ values. The results indicate that removal of $\mathrm{MB}$ is less sensitive to the initial $\mathrm{pH}$ variation of the dye solution and remains almost constant over the $\mathrm{pH}$ range $6-10$. Further, an overall positive charge and repulsion of $\mathrm{MB}$ is expected when the solution $\mathrm{pH}$ drops below the $\mathrm{pH}_{\mathrm{PZC}}$ of 7.17. However, maximum sorptive capacity was maintained below the $\mathrm{pH}_{\mathrm{PZC}}$ until the $\mathrm{pH}$ had decreased to 2. Similar sorptive capacities within this $\mathrm{pH}$ range are likely the result of the number of adsorption sites being in excess of the number of MB molecules despite changes in $\mathrm{pH}$ potentially changing the ratio of positive and negative charges on the adsorbent surface. An excess of adsorption sites is consistent with the increase in specific surface area (shown in Tables 1,2) for SKOH. The decrease in sorptive capacity at $\mathrm{pH} 2$ is likely to result from the presence of excess $\mathrm{H}^{+}$ions competing with the cationic MB molecules and protonating negatively charged adsorbent sites, thereby reducing $\mathrm{MB}$ adsorption.

For SHP at $\mathrm{pH}$ conditions above the $\mathrm{pH}_{\mathrm{PZC}}$ of 3.04 , there was a trend toward increasing sorptive capacities as $\mathrm{pH}$ increased to 10 . As the excess hydroxyl $\left(-\mathrm{OH}^{-}\right)$ions increased, surface functional groups were predominantly deprotonated resulting in an enhanced number of adsorption sites available for binding positively charged MB adsorbate [22, 35].

\section{Effect of adsorbent dosage}

The adsorbent dosage is a major parameter because this concludes the capacity of a adsorbent for given initial concentration of the adsorbate at the operating conditions. Doses in the range of $1-10 \mathrm{~g} / \mathrm{L}$ were used in adsorption experiments with an $\mathrm{MB}$ concentration of $300 \mathrm{mg} / \mathrm{L}$ to investigate the effect of adsorbent amount. The sorptive capacities at a dose of $1 \mathrm{~g} / \mathrm{L}$ indicate that extremely low sorptive capacities would be observed at doses below $1 \mathrm{~g} / \mathrm{L}$ for SW and SHP. Thus, doses below $1 \mathrm{~g} / \mathrm{L}$ were not investigated. The results are shown in Fig. 7.

The percentage removal by individual sorbents increased with increasing dosage, although maximum sorptive capacities were reached at SW and SKOH doses of $5 \mathrm{~g} / \mathrm{L}$ and then remained almost constant. In comparison, the percentage removal of MB onto SHP was poor and the optimum dosage was not reached at the range of doses investigated. The increased removal with dosage was expected because of the increased adsorbent surface area and availability of adsorption sites [12,36]. This study demonstrates that optimum amounts of adsorbent may be established for specific dye concentrations.

\section{Evaluation of adsorption behavior of adsorbents}

\section{Adsorption isotherm}

Adsorption isotherms are often used to give an accurate description of adsorption behavior for design purposes. The 


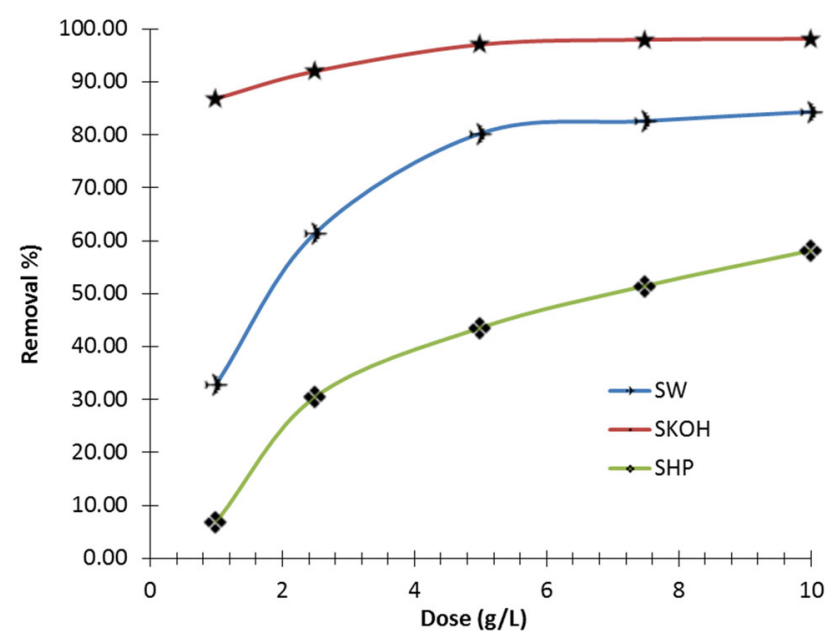

Fig. 7 Effect of adsorbent dosage on the adsorption of MB on SW, SKOH and SHP $\left(C_{0}=300 \mathrm{mg} / \mathrm{L}\right.$; working volume $=100 \mathrm{~mL}$; initial $\mathrm{pH}=$ ambient; agitation speed $=250 \mathrm{rpm}$ )

initial dye concentrations within the range from 0 to $1000 \mathrm{ppm}$ were indicative of the completion of a monolayer by the leveling of the isotherm adsorption, thus preventing further adsorption leading to multilayer coverage in (Fig. 8). The equilibrium isotherms were analyzed by the following: Langmuir, Freundlich, Tempkin, DubininRaduskevich (D-R) isotherm models. The nonlinear and linearized equations are represented by the expression in Table 3 and the results obtained from the best fitting isotherm models are shown in Table 1. The method of least squares was used for obtaining the isotherm constants, and error analysis using the following functions [37] confirmed the model of best fit: sum of squares of errors (SSE), sum of absolute errors (EABS), average relative error (ARE) and nonlinear Chi-test $(\chi)$ as shown in Table 4. The Langmuir isotherm model could be used to describe the adsorption behavior of all adsorbents; all other models were a poor fit and so treatment of the adsorption behavior is shown in Table 1.

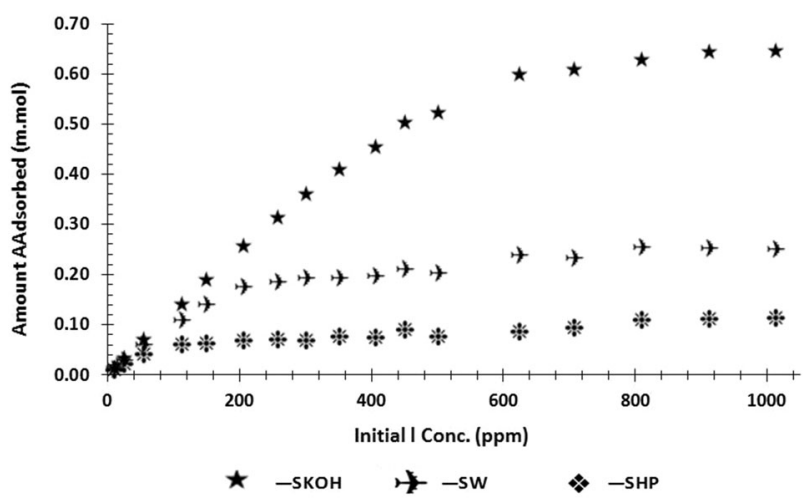

Fig. 8 Variation of the extent of removal of MB by SW, SKOH and SHP as a function of initial dye concentration
A dimensionless constant separation factor or equilibrium parameter, $R_{L}$, is defined according to the following equation [38]:

$R_{L}=\frac{1}{\left(1+K_{L} C_{0}\right)}$,

where $C_{O}$ is the initial dye concentration $(\mathrm{mg} / \mathrm{L})$. The $R_{L}$ value indicates whether the isotherm is favorable $\left(0<R_{L}<1\right)$, unfavorable $\left(R_{\mathrm{L}}>1\right)$, linear $\left(R_{L}=1\right)$ or irreversible $\left(R_{L}=0\right)$. Coefficients of determination $\left(\mathrm{R}^{2}\right)$ values above 0.99 for all adsorbents are listed in Table 1 and indicate that the Langmuir isotherm fits the experimental data well. The Langmuir isotherm model suggests that monolayer adsorption onto a homogeneous surface is applicable for these adsorbents.

Of these four isotherm models represented in Table 5, error analyses show that the Langmuir model is the best to describe the biosorption of MB on SW, SKOH and SHP. All the error analyses for the Langmuir model give much reasonably close $R^{2}$ and lower errors indicating that it is overall a better fit. The biosorption capacity of $\mathrm{MB}$ on SKOH is determined to be $0.665 \mathrm{mmol} \mathrm{g}^{-1}$ based on the Langmuir model, which is higher than the value obtained for the Freundlich, Temkin and Dubinin-Radushkevich model when compared with experimental data. Maximum sorption capacity of $36.8 \mathrm{mg} \mathrm{g}^{-1}$ for SHP showed a decrease in adsorption capacity, and a significant improvement was observed for SKOH $\left(212.8 \mathrm{mg} \mathrm{g}^{-1}\right)$ over SW (83.5 $\mathrm{mg} \mathrm{g}^{-1}$ ) in Table 1. Hence, Langmuir models can be used to describe the adsorption isotherm of MB on SW, SKOH and SHP, with the Langmuir model giving a better $R^{2}$ and lower errors in general. These results indicate that adsorption of $\mathrm{MB}$ on $\mathrm{SKOH}$ is stronger than that of SW and SHP on the different adsorbent. This could be due to the less bulky nature of SKOH than that of others, enabling more $\mathrm{MB}$ molecules to be adsorbed on the adsorbent.

A comparison of maximum adsorption capacities for MB with various biosorbents is summarized in Table 6 . Only a few biosorbents had higher sorption capacities than $\mathrm{SKOH}$; key considerations in which SKOH may prove more advantageous, however, are the availability and simple processing requirements of the adsorbent. Adsorbents may be considered low cost if they are abundant, require little processing and have low economic value [39]. As mentioned previously, sago hampas waste is readily available in the Asia-Pacific region as an agricultural waste that can be sourced at free cost. Furthermore, the chemical modification of the sago waste to $\mathrm{SKOH}$ was experimented in achieving high sorption capacities compared with previously reported biosorbents and was achieved here by a simple modification technique that requires few procedural steps. On the other hand, it can be considered as a good 
Table 3 Isotherm model equations

\begin{tabular}{llll}
\hline Isotherm model & Linear & Non-linear & Plot \\
\hline Langmuir & $\frac{C_{e}}{q_{e}}=\frac{1}{q_{\max } K_{L}}+\frac{1}{q_{\max }} C_{e}$ & $q_{e}=\frac{q_{\max } K_{L} C_{e}}{1+K_{L} C_{e}}$ & $\frac{C_{e}}{q_{e}} \mathrm{vs} C_{e}$ \\
Freundlich & $\log q_{e}=\log K_{F}+\frac{1}{n} \log C_{e}$ & $q_{e}=K_{F} C_{e}^{1 / n}$ & $\log q_{e}$ vs $\ln C_{e}$ \\
Temkin & $q_{e}=B \ln K_{T}+B \ln C_{e}$ & & $q_{e}$ vs $\ln C_{e}$ \\
& & $q_{e}=(R T / b) \ln \left(K_{T} C_{e}\right)$ & \\
Dubinin-Radushkevich & $B=\frac{R T}{b}$ & & \\
& $\ln q_{e}=\ln q_{D}-B \varepsilon^{2}$ & $q_{e}=\left(q_{D}\right) \exp \left(-k_{a d} \varepsilon^{2}\right)$ & $\ln q_{e}$ vs $\varepsilon^{2}$ \\
& $\varepsilon=R T \ln \left[1+\frac{1}{C_{e}}\right]$ & & \\
& $E=\frac{1}{\sqrt{-2 B}}$ & & \\
\hline
\end{tabular}

$q_{e}$ is the amount of dye adsorbed, $C_{e}$ is the equilibrium concentration of the dye, $q_{\max }$ is the maximum adsorption capacity $(\mathrm{mg} / \mathrm{g}), \mathrm{K}_{\mathrm{F}}\left(\mathrm{mg}^{1}{ }^{-1 / \mathrm{n}} \mathrm{L}^{1 / \mathrm{n}} \mathrm{g}^{-1}\right)$ is the Freundlich constant, $\mathrm{n}$ is the empirical parameter which is related to the biosorption intensity, $\mathrm{K}_{\mathrm{T}}$ is the equilibrium binding constant $(\mathrm{L} / \mathrm{mmol})$ corresponding to the maximum binding energy, constant $B$ is related to the heat of adsorption, $R$ is gas constant, $T$ is the absolute temperature, $\beta$ gives the mean free energy, $E$ is the sorption per molecule of sorbate
Table 4 Error functions

\begin{tabular}{lll}
\hline Error function & Abbreviation & Definition/expression \\
\hline Sum squares errors & ERRSQ/SSE & $\sum_{i=1}^{n}\left(q_{e, \text { calc }}-q_{e, \text { meas }}\right)_{1}^{2}$ \\
Average relative error & ARE & $\frac{100}{n} \sum_{i=1}^{n} \mid \frac{q_{e, \text { meas }}-q_{e, \text { alc }}}{q_{e, \text { maas }}}$ \\
Sum of absolute error & EABS & $\sum_{i=1}^{n}\left|q_{e, \text { meas }}-q_{e, \text { calc }}\right|_{i}$ \\
Nonlinear chi-square test & $\chi^{2}$ & $\sum_{i=1}^{n} \frac{\left(q_{e, \text { meas }}-q_{e, \text { calc }}\right)^{2}}{q_{e, \text { meas }}}$ \\
\hline
\end{tabular}

biosorbent in the context of its higher qmax value as it is able to remove MB better than many other treated biosorbents, such as citric/EDTA-modified alkali rice straw, citric acid-modified kenaf core fibers, sulfuric acid- treated parthenium and EDTA-modified rice husk given in Table 6.

Advantages over other biosorbents for SKOH may also include a less energy-intensive treatment process. For example, modification by the alkali treatment process is less energy intensive than biosorbent treatments that require high temperatures to produce activated carbon (e.g., activated carbon from apricot [40] and sago waste carbon [41]. Less intensive processing requirements for $\mathrm{SKOH}$ suggests potentially lower expenses in the use of this biosorbent.

\section{Adsorption kinetics}

A kinetic study of adsorption is necessary as it provides the information about the adsorption mechanism, which is
Table 5 Comparison of parameters for $R^{2}$ and error functions using different isotherm models

\begin{tabular}{lllllll}
\hline Adsorbent & Models & $R^{2}$ & EABS & EERSQ/SSE & ARE & $\chi$ \\
\hline SW & Langmuir & 0.9917 & 0.204 & 0.003 & 0.210 & 0.030 \\
& Freundlich & 0.9307 & 0.469 & 0.020 & 0.524 & 0.102 \\
& Temkin & 0.9724 & 1.471 & 0.130 & 2.267 & 1.814 \\
& Dubinin-Radushkevich (D-R) & 0.6407 & 0.850 & 0.059 & 0.985 & 0.650 \\
\multirow{3}{*}{ SKOH } & Langmuir & 0.9979 & 0.152 & 0.013 & 0.204 & 0.060 \\
& Freundlich & 0.9025 & 0.614 & 0.040 & 0.637 & 0.134 \\
& Temkin & 0.9864 & 0.233 & 0.007 & 0.548 & 0.101 \\
& Dubinin-Radushkevich (D-R) & 0.6701 & 1.055 & 0.136 & 1.153 & 0.770 \\
SHP & Langmuir & 0.9488 & 0.101 & 0.002 & 0.200 & 0.030 \\
& Freundlich & 0.9217 & 0.121 & 0.001 & 0.384 & 0.021 \\
& Temkin & 0.9274 & 0.105 & 0.001 & 0.329 & 0.015 \\
& Dubinin-Radushkevich (D-R) & 0.7133 & 0.267 & 0.007 & 0.559 & 0.131 \\
\hline
\end{tabular}


Table 6 Comparison of the maximum monolayer g) of MB dye on various biomass-based adsorbents adsorption capacities, $q_{\max }(\mathrm{mg} /$

\begin{tabular}{lll}
\hline Adsorbent & Adsorption capacity $(\mathrm{mg} / \mathrm{g})$ & Reference \\
\hline Untreated waste & & \\
Untreated (Metroxylon sagu) waste & 83.48 & This study \\
Pine cone biomass & 109.89 & {$[10]$} \\
Cucumber peels & 111.11 & {$[11]$} \\
Watermelon seed hulls & 57.14 & {$[11]$} \\
Grape pulp & 153.85 & {$[15]$} \\
Peanut husk & 72.13 & {$[46]$} \\
Spent rice biomass & 8.3 & {$[47]$} \\
Treated waste & & \\
Potassium hydroxide-treated (Metroxylon sagu) waste & 212.8 & This study \\
Phosphoric acid treated (Metroxylon sagu) waste & 36.82 & This study \\
Citric and/or EDTA-modified alkali rice straws & $62.90-135.10$ & {$[22]$} \\
Activated carbon from apricot & 136.98 & {$[40]$} \\
Citric acid-modified rice straw & 270.3 & {$[48]$} \\
Citric acid-modified kenaf core fibers & 131.6 & {$[18]$} \\
Sulfuric acid-treated parthenium & 88.29 & {$[49]$} \\
EDTA-modified rice husk & 46.30 & {$[23]$} \\
Sago waste carbon & 4.51 & {$[41]$} \\
HCL-treated meranti sawdust & 120.48 & {$[12]$} \\
TA-modified bagasse & 69.93 & {$[13]$} \\
NaOH-modified durian leaf powder & 125 & {$[14]$} \\
\hline
\end{tabular}

Table 7 Kinetic model equations

\begin{tabular}{lll}
\hline Kinetic models & Equation & Plot \\
\hline Pseudo-first-order model & $\log \left(q_{e}-q_{t}\right)=\log q_{e}-\frac{K_{1}}{2.303} t$ & $\log \left(q_{e}-q_{t}\right)$ vs $t$ \\
Pseudo-second-order model & $\frac{t}{q_{t}}=\frac{1}{k_{2} q_{e}^{2}}+\frac{1}{q_{e}} t$ & $\frac{t}{q_{t}}$ vs $t$ \\
Elovich model & $q_{t}=\left(\frac{1}{b}\right) \ln (a b)+\frac{1}{b} \ln t$ & $q_{t}$ vs $\ln t$ \\
Intra-particle diffusion model & $q_{t}=k_{i d} t^{1 / 2}+C$ & $q_{t}$ vs $t^{1 / 2}$ \\
\hline
\end{tabular}

$q_{e}$ and $q_{t}$ are the amounts of $\mathrm{MB}$ adsorbed $\left(\mathrm{mg} \mathrm{g}^{-1}\right)$ at equilibrium and at time $t$ (min), respectively; $k_{1}$ $\left(\mathrm{min}^{-1}\right)$ is the adsorption rate constant; $k_{2}\left(\mathrm{~g} \mathrm{mg}^{-1} \mathrm{~min}^{-1}\right)$ is the rate constant of second-order adsorption; $\mathrm{k}_{1} \mathrm{~d}(\mathrm{mg} / \mathrm{g} \mathrm{h})$ is the intraparticle diffusion rate constant and $C$ gives an idea about the thickness of the boundary layer; $a(\mathrm{mg} / \mathrm{g} \mathrm{h})$ is the initial sorption rate and $b(\mathrm{~g} / \mathrm{mg})$ is related to the extent of surface coverage and activation energy for chemisorption crucial for the practicality of the process. The pseudo-firstorder, pseudo-second-order, intraparticle diffusion and Elovich models were implemented to evaluate the rate constant of the adsorption process for SW, SHP and SKOH samples onto $\mathrm{MB}$ at various initial concentrations. The experimental data were fitted with the kinetic models linearized equations in Table 7 and the linear regression analyses and the constants were calculated by using Microsoft Excel, Version 2010. The experimental and calculated qe values from the related plots together with the model constants and correlation coefficient $\mathrm{R}^{2}$ determined from the kinetic models for sorption of $\mathrm{MB}$ onto SW, SHP and SKOH samples at $30{ }^{\circ} \mathrm{C}$ are summarized in Table 8 . The validity of the exploited models is verified by the experimental qe exp and correlation coefficient $\mathrm{R}^{2}$.
In the case of the pseudo-first-order kinetic model values proposed by Lagergren [42] in Table 8, low linear regression correlation coefficients $\left(R^{2}<0.9\right)$ indicated poor agreement between the model and experimental data. The experimental equilibrium uptakes, $q_{e}$, exp $(\mathrm{mg} / \mathrm{g})$, do not concur with the calculated $q_{e}, \mathrm{cal}(\mathrm{mg} / \mathrm{g})$ values from the pseudo-first-order model which reflect that experimental data obtained for sorption of the MB under investigation fails to predict the sorption process for the entire region of contact time. The rate constant, $k_{1}$, obtained for the pseudofirst-order model do not show a consistent trend with increasing concentration range for MB studied as most $R^{2}$ values are relatively small.

However, the linear form of pseudo-second-order equation proposed by Ho and McKay [43] was found to be 


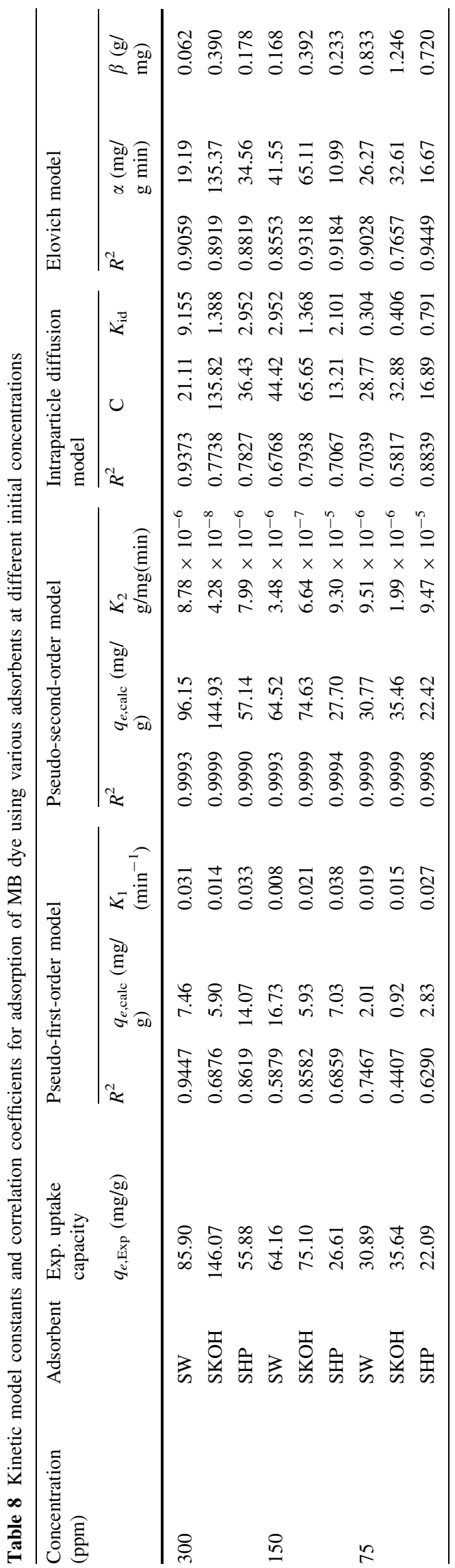

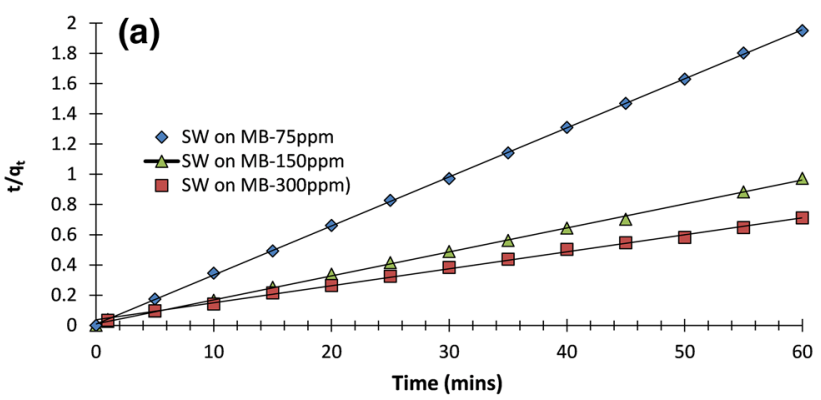
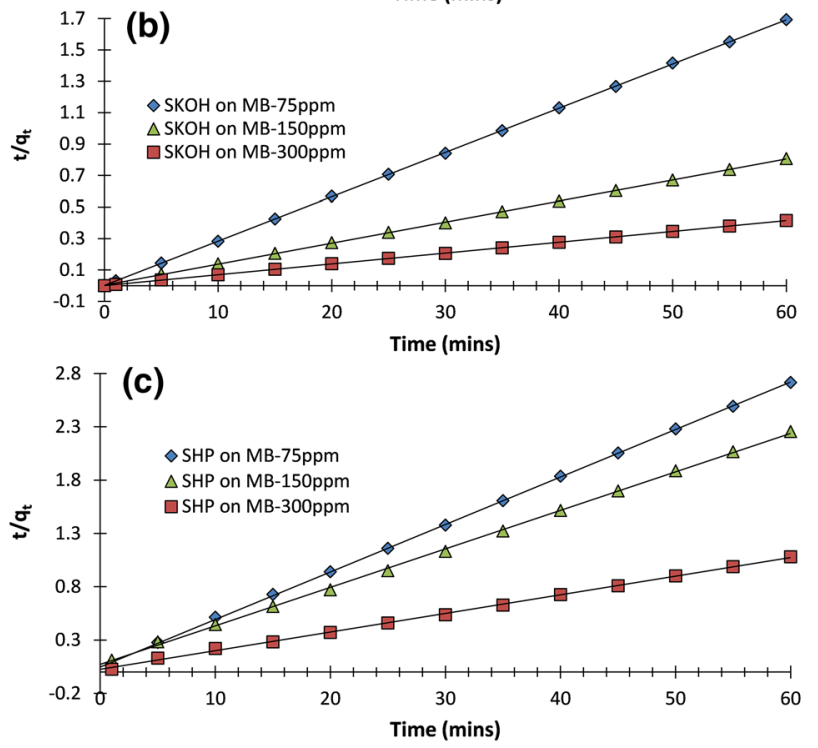

Fig. 9 Pseudo-second-order kinetics model for adsorption of MB on a SW, b SKOH and c SHP

able to predict the behavior of the sorption process for all the range of concentrations studied here. The linear plots of $t / q_{t}$ against $t(\mathrm{~min})$ gives $1 / q_{e}(\mathrm{cal})$ as the slope and $1 / k_{2} q_{e}^{2}$ as the intercept, where $\mathrm{k}_{2}(\mathrm{~g} / \mathrm{mg}$-min) is the rate constant of the second-order adsorption as shown in Table 8 and Fig. 9. It is observed that the regression lines are almost superimposed by the experimental data. $R^{2}$ values between 0.9990 and 0.9999 and calculated $q_{e}$ values similar to those determined experimentally indicated that MB adsorption obeyed pseudo-second-order kinetics for all adsorbents, whereby an assumption of the model is that the rate of chemisorption is a significant factor in determining adsorption rates.

The values of the intraparticle diffusion model by Weber and Morris [43] constants $\left(k_{\mathrm{id}}\right.$ and $C$ ) obtained for all adsorbent system together with the $R^{2}$ values obtained are presented in Table 8. Positive $C$ values indicated that intraparticle diffusion was not solely the rate-determining step and that other factors contribute to the rate of adsorption. This is particularly the case at higher MB concentrations where larger $C$ values indicate a greater degree of boundary layer control and deviation from the intraparticle diffusion model. $R^{2}$ values also indicated a 
poor agreement of experimental data with the pseudosecond-order kinetic model. Contributors to adsorption rates that lead to positive $C$ values may include other diffusion mechanisms (e.g., film diffusion) or chemisorption, as found earlier by the agreement with pseudo-secondorder kinetics. However, their contributions to the adsorption rate cannot be deduced from this model. Linear plots with reasonable $R^{2}$ values indicate agreement with chemisorption processes contributing significantly to adsorption rates.

Elovich equation, described by Chien and Clayton [45], is another most frequently used model for depicting chemisorption process and is expressed by Equation in Table 7. It is observed that the values of $\alpha\left(\mathrm{mg} \mathrm{g}^{-1} \mathrm{~min}^{-1}\right)$ increase with the increase of initial concentration range studied. The values of the regression coefficient $\left(R^{2}=0.79-0.98\right)$ of the Elovich kinetic model suggest that kinetic data did not follow the Elovich model. However, the higher values of the Elovich constants, $\alpha\left(\mathrm{mg} \mathrm{g}^{-1}\right.$ $\left.\min ^{-1}\right)$ and $\beta\left(\mathrm{g} \mathrm{mg}^{-1}\right)$, as shown in Table 8 are suggestive of an increased rate of chemisorption. However, experimental data again showed better agreement with the pseudo-second-order kinetic model where the $R^{2}$ values obtained for other three kinetics models are less than 0.9, and the majority of the data do not fall on a straight line, indicating that these models are inappropriate.

\section{Conclusions}

The chemical treatment of adsorbents has been shown here to have significant effects on the adsorption capacity of sago waste powder on basic dyes such as methylene blue. Acid treatment resulted in a lower adsorbent surface area that subsequently reduced the adsorption capacity. However, alkaline treatment demonstrated the effectiveness of using chemical treatment to enhance the adsorption capacity of biosorbents. The treatment process increased the porosity and surface area of the sago waste powder, thereby increasing the number of adsorption sites. The adsorption capacity and kinetics for the adsorbents investigated were well described by the monolayer adsorption model of the Langmuir isotherm and the chemisorption model of pseudo-second-order kinetics. An improvement in the maximum adsorption capacity was observed for the alkali-treated sago waste with an adsorption capacity more than double that exhibited by the untreated sago waste. Maximum adsorption capacities of 83.5, 212.8 and $36.8 \mathrm{mg} / \mathrm{g}$ were found for untreated, alkali-treated and acid-treated sago wastes, respectively. The alkali-treated sago waste also showed significant improvement over a wide range of biosorbents previously reported. The sago waste used in this investigation is a low-cost agricultural waste found abundantly in the Asia-Pacific region. The alkali treatment was a simple process that requires few procedural steps, avoids energy-intensive heat treatment and shows potential for implementation on wastewater treatment. We propose that alkali-treated sago waste represents an effective and economically feasible material for the treatment of dye-containing effluents.

Acknowledgments The authors thank the Government of Brunei Darussalam and the Universiti Brunei Darussalam (UBD) for their financial support and the award of a $\mathrm{PhD}$ scholarship to JOA. The authors are grateful to the Bioenvironmental Engineering Research Unit (BERU), Faculty of Engineering, International Islamic University Malaysia for providing the laboratory support and facilities.

\section{Compliance with ethical standards}

Conflict of interest The authors have no conflicts of interest to declare.

Open Access This article is distributed under the terms of the Creative Commons Attribution 4.0 International License (http://crea tivecommons.org/licenses/by/4.0/), which permits unrestricted use, distribution, and reproduction in any medium, provided you give appropriate credit to the original author(s) and the source, provide a link to the Creative Commons license, and indicate if changes were made.

\section{References}

1. Chatterjee S, Lee DS, Lee MW, Woo SH (2009) Enhanced adsorption of congo red from aqueous solutions by chitosan hydrogel beads impregnated with cetyl trimethyl ammonium bromide. Bioresour Technol 100(11):2803-2809

2. Yao Z, Wang L, Qi J (2009) Biosorption of methylene blue from aqueous solution using a bioenergy forest waste: Xanthoceras sorbifolia seed coat. Clean Soil Air Water 37(8):642-648

3. Nigam P, Armour G, Banat IM, Singh D, Marchant R (2000) Physical removal of textile dyes from effluents and solid-state fermentation of dye-adsorbed agricultural residues. Bioresour Technol 72(3):219-226

4. Tan IAW, Hameed BH, Ahmad AL (2007) Equilibrium and kinetic studies on basic dye adsorption by oil palm fibre activated carbon. Chem Eng J 127:111-119

5. Ahmad A, Mohd-Setapar SH, Chuong CS, Khatoon A, Wani WA, Kumar R, Rafatullah M (2015) Recent advances in new generation dye removal technologies: novel search for approaches to reprocess wastewater. RSC Adv 5(39):30801-30818

6. El-Latif MA, Ibrahim AM, El-Kady M (2010) Adsorption equilibrium, kinetics and thermodynamics of methylene blue from aqueous solutions using biopolymer oak sawdust composite. J Am Sci 6(6):267-283

7. Ghaedi M, Hassanzadeh A, Kokhdan SN (2011) Multiwalled carbon nanotubes as adsorbents for the kinetic and equilibrium study of the removal of alizarin red S and morin. J Chem Eng Data 56(5):2511-2520

8. Vimonses V, Lei S, Jin B, Chow CWK, Saint C (2009) Kinetic study and equilibrium isotherm analysis of Congo Red adsorption by clay materials. Chem Eng J 148:354-364

9. Mohammad M, Maitra S, Ahmad N, Bustam A, Sen T, Dutta BK (2010) Metal ion removal from aqueous solution using physic seed hull. J Hazard Mater 179(1):363-372 
10. Sen TK, Afroze S, Ang H (2011) Equilibrium, kinetics and mechanism of removal of methylene blue from aqueous solution by adsorption onto pine cone biomass of Pinus radiata. Water Air Soil Pollut 218(1-4):499-515

11. Akkaya G, Güzel F (2014) Application of some domestic wastes as new low-cost biosorbents for removal of methylene blue: kinetic and equilibrium studies. Chem Eng Commun 201(4):557-578

12. Ahmad A, Rafatullah M, Sulaiman O, Ibrahim M, Hashim R (2009) Scavenging behaviour of meranti sawdust in the removal of methylene blue from aqueous solution. J Hazard Mater 170(1):357-365

13. Low LW, Teng TT, Rafatullah M, Morad N, Azahari B (2013) Adsorption studies of methylene blue and malachite green from aqueous solutions by pretreated lignocellulosic materials. Sep Sci Technol 48(11):1688-1698

14. Hussin ZM, Talib N, Hussin NM, Hanafiah MA, Khalir WK (2015) Methylene blue adsorption onto $\mathrm{NaOH}$ modified durian leaf powder: isotherm and kinetic studies. Am J Environ Eng 5(3A):38-43

15. Saygili H, Akkaya Saygili G, Güzel F (2014) Using grape pulp as a new alternative biosorbent for removal of a model basic dye. Asia Pac J Chem Eng 9(2):214-225

16. Vakili M, Rafatullah M, Salamatinia B, Abdullah AZ, Ibrahim MH, Tan KB, Gholami Z, Amouzgar P (2014) Application of chitosan and its derivatives as adsorbents for dye removal from water and wastewater: a review. Carbohydr Polym 113:115-130

17. Thakur VK, Thakur MK (2014) Recent advances in graft copolymerization and applications of chitosan: a review. ACS Sustain Chem Eng 2(12):2637-2652

18. Sajab MS, Chia CH, Zakaria S, Jani SM, Ayob MK, Chee KL, Khiew PS, Chiu WS (2011) Citric acid modified kenaf core fibres for removal of methylene blue from aqueous solution. Bioresour Technol 102(15):7237-7243

19. Rafatullah M, Sulaiman O, Hashim R, Ahmad A (2010) Adsorption of methylene blue on low-cost adsorbents: a review. J Hazard Mater 177(1):70-80

20. Han R, Zhang L, Song C, Zhang M, Zhu H, Zhang L (2010) Characterization of modified wheat straw, kinetic and equilibrium study about copper ion and methylene blue adsorption in batch mode. Carbohydr Polym 79(4):1140-1149

21. Azlan K, Wan Saime WN, Lai Ken L (2009) Chitosan and chemically modified chitosan beads for acid dyes sorption. J Environ Sci 21(3):296-302

22. Fathy NA, El-Shafey OI, Khalil LB (2013) Effectiveness of alkali-acid treatment in enhancement the adsorption capacity for rice straw: the removal of methylene blue dye. ISRN Phys Chem 2013:15. doi:10.1155/2013/208087

23. Ong S-T, Keng P-S, Lee C-K (2010) Basic and reactive dyes sorption enhancement of rice hull through chemical modification. Am J Appl Sci 7(4):447-452

24. Prasad RN, Viswanathan S, Devi JR, Rajkumar J, Parthasarathy N (2008) Kinetics and equilibrium studies on biosorption of CBB by coir pith. Am Eurasian J Sci Res 3(2):123-127

25. Vijayaraghavan K, Yun Y-S (2008) Bacterial biosorbents and biosorption. Biotechnol Adv 26(3):266-291

26. Awg-Adeni D, Abd-Aziz S, Bujang K, Hassan MA (2010) Bioconversion of sago residue into value added products. Afr J Biotechnol 9(14):2016-2021

27. Kaewprasit C, Hequet E, Abidi N, Gourlot JP (1998) Quality measurements. J Cotton Sci 2:164-173

28. Linggang S, Phang L, Wasoh M, Abd-Aziz S (2012) Sago pith residue as an alternative cheap substrate for fermentable sugars production. Appl Biochem Biotechnol 167(1):122-131

29. Tan W-f, Lu S-j, Liu F, Feng X-h, J-z He, Koopal LK (2008) Determination of the point-of-zero charge of manganese oxides with different methods including an improved salt titration method. Soil Sci 173(4):277-286

30. Goertzen SL, Theriault KD, Oickle AM, Tarasuk AC, Andreas HA (2010) Standardization of the Boehm titration. Part I. $\mathrm{CO}_{2}$ expulsion and endpoint determination. Carbon 48(4):1252-1261

31. Özsgn G (2011) Production and Characterization of Activated Carbon from Pistachio-Nut Shell. Middle East Technical University. Master Thesis

32. El-Sonbati AZ, El-Deen IM, El-Bindary MA (2016) Adsorption of Hazardous Azorhodanine Dye from an Aqueous Solution Using Rice Straw Fly Ash. J Disper Sci Technol 37(5):715-722

33. Chakraborty S, Chowdhury S, Das Saha P (2011) Adsorption of crystal violet from aqueous solution onto $\mathrm{NaOH}$-modified rice husk. Carbohydr Polym 86(4):1533-1541

34. Shahryari Z, Goharrizi AS, Azadi M (2010) Experimental study of methylene blue adsorption from aqueous solutions onto carbon nano tubes. Int J Water Res Environ Eng 2(2):16-28

35. Mahmoud DK, Salleh MAM, Karim WAWA, Idris A, Abidin ZZ (2012) Batch adsorption of basic dye using acid treated kenaf fibre char: equilibrium, kinetic and thermodynamic studies. Chem Eng J 181-182:449-457

36. Garg V, Kumar R, Gupta R (2004) Removal of malachite green dye from aqueous solution by adsorption using agro-industry waste: a case study of Prosopis cineraria. Dyes Pigm 62(1):1-10

37. Gimbert F, Morin-Crini N, Renault F, Badot P-M, Crini G (2008) Adsorption isotherm models for dye removal by cationized starch-based material in a single component system: error analysis. J Hazard Mater 157(1):34-46

38. Chien SH, Clayton WR (1980) Application of Elovich equation to the kinetics of phosphate release and sorption in soils. Soil Sci Soc Am J 44:265

39. Zwain HM, Vakili M, Dahlan I (2014) Waste material adsorbents for zinc removal from wastewater: a comprehensive review. Int J Chem Eng 2014:13. doi:10.1155/2014/347912

40. Basar CA (2006) Applicability of the various adsorption models of three dyes adsorption onto activated carbon prepared waste apricot. J Hazard Mater 135:232-241

41. Kadirvelu K, Kavipriya M, Karthika C, Radhika M, Vennilamani N, Pattabhi S (2003) Utilization of various agricultural wastes for activated carbon preparation and application for the removal of dyes and metal ions from aqueous solutions. Bioresour Technol 87(1):129-132

42. Lagergren S (1898) About the theory of so-called adsorption of soluble substances. Kungliga Sven Vetensk Handl 24(4):1-39

43. Ho Y-S, McKay G (1998) Kinetic models for the sorption of dye from aqueous solution by wood. Process Saf Environ Prot 76(2):183-191

44. Weber WJ, Morriss JC (1963) Kinetics of adsorption on carbon from solution. J Sanit Eng Div Am Soc Civil Eng 89:31-60

45. Chien S, Clayton W (1980) Application of Elovich equation to the kinetics of phosphate release and sorption in soils. Soil Sci Soc Am J 44(2):265-268

46. Song J, Zou W, Bian Y, Su F, Han R (2011) Adsorption characteristics of methylene blue by peanut husk in batch and column modes. Desalination 265(1):119-125

47. Rehman MSU, Kim I, Han J-I (2012) Adsorption of methylene blue dye from aqueous solution by sugar extracted spent rice biomass. Carbohydr Polym 90(3):1314-1322

48. Gong R, Zhong K, Hu Y, Chen J, Zhu G (2008) Thermochemical esterifying citric acid onto lignocellulose for enhancing methylene blue sorption capacity of rice straw. J Environ Manage 88(4):875-880

49. Lata H, Garg V, Gupta R (2007) Removal of a basic dye from aqueous solution by adsorption using Parthenium hysterophorus: an agricultural waste. Dyes Pigm 74(3):653-658 